\title{
THE IMPORTANCE OF PROMOTING MULTIMODAL TEACHING IN THE FOREIGN LANGUAGE CLASSROOM FOR THE ACQUISITION OF SOCIAL COMPETENCES: PRACTICAL EXAMPLES
}

\author{
MARÍA MARTÍNEZ LIROLA ${ }^{1}$ \\ University of Alicante (Spain)
}

\begin{abstract}
This article analyses the way in which the subject English Language $V$ of the degree English Studies (English Language and Literature) combines the development of the five skills (listening, speaking, reading, writing and interacting) with the use of multimodal activities and resources in the teaching-learning process so that students increase their motivation and acquire different social competences that will be useful for the labour market such as communication, cooperation, leadership or conflict management.
\end{abstract}

This study highlights the use of multimodal materials (texts, videos, etc.) on social topics to introduce cultural aspects in a language subject and to deepen into the different social competences university students can acquire when they work with them. The study was guided by the following research questions: how can multimodal texts and resources contribute to the development of the five skills in a foreign language classroom? What are the main social competences that students acquire when the teaching-learning process is multimodal? The results of a survey prepared at the end of the academic year 2015-2016 point out the main competences that university students develop thanks to multimodal teaching.

For its framework of analysis, the study draws on the main principles of visual grammar (Kress \& van Leeuwen, 2006) where students learn how to analyse the main aspects in multimodal texts. The analysis of the different multimodal activities described in the article and the survey reveal that multimodality is useful for developing critical thinking, for bringing cultural aspects into the classroom and for working on social competences. This article will explain the successes and challenges of using multimodal texts with social content so that students can acquire social competences while learning content. Moreover, the implications of using multimodal resources in a language classroom to develop multiliteracies will be observed.

Key words: Multimodality, visual grammar, competences, skills, teaching-learning process.

\section{Introduction}

Technology has been developed in the last decades, which has involved changes in the ways of communication and also in the definition of 'literacy'2 and its applications in educational contexts in the 21 st century (Lemke, 2012; Livingstone, 2008; Merchant, 2009). There are many changes in this new context and consequently, high education requests the development of new tools and techniques in the teachinglearning process such as the use of technology or multimodal resources in the classroom apart from the traditional techniques or materials.

There were many teachers who were already incorporating intuitively multimodal practices and elements to their teaching practices, i.e., they were using texts with more than one mode of communication where images were important, as Knox makes clear (2008, p.140):

\footnotetext{
1 E-mail: maria.lirola@ua.es

2 By 'literacy' is understood the capacity of expression using the different skills (listenings, speaking, reading, writing and interaction).
} 
Multimodal perspectives on language and language education have only recently appeared in the literature on $\mathrm{L} 2$ teaching and learning. A brief consideration of the classroom practices of teachers and students shows very quickly, though, that multimodality is something that language teachers have understood intuitively for a long time.

The applications of the principles of the European Higher Education Area (EHEA) in the last decade involve a deep reorganization of higher education in general and of teaching at tertiary education in particular. One of the main changes consists on students becoming the protagonists of their learning process and on giving importance to the acquisition of some competences that will be essential for their future as professionals in the labour market (Benito \& Cruz, 2005; Bueno González \& Nieto García, 2009; López Noguero, 2005; Martínez Lirola, 2007). In this sense, getting used to the new demands of the EHEA becomes a challenge for teachers and students because pedagogy needs to be developed in such a way that multimodal resources and technology can contribute to the significant learning of students and to the effective and real development of skills.

The changes already mentioned in the previous paragraphs have consequences in pedagogy and request pointing out the necessary elements for the production of texts in virtual environments (Healy, 2008). The concepts and applications of 'multiliteracies' have been extended in the last years thanks to the work of Unsworth $(2001,2008 a, 2008 b, 2010)$. He concentrates on the way in which multiliteracies are present in the classroom, giving special attention to the relationships between the texts and the image and to the way different meanings are created taking into consideration the different modes of communication that are chosen.

The traditional 'literacy' has concentrated mainly on the written language. The other ways of communication (visual, musical, etc.) were backgrounded (Coffin, 2012; Hestbaek, Maeger $\phi$ \& Tonnessen, 2015). In this era of digital 'literacy' the priority is that students learn through the use of different modes of communication so that they develop and use multimodal texts, Power Point presentations, web pages, videos, debates through social networks such as Facebook, etc. The era 2.0 offers multiple possibilities that enrich the teaching-learning process because it allows that students write and read in virtual environments and add videos and photographs in the development of their skills. In addition, students are able to analyse, deconstruct and design multimodal texts, which contribute to the development of critical thinking and to the acquisition of social competences such as leadership, conflict solving and cooperation. Following Simpson and Walsh (2010, p. 37): "Now with interactive, multiple authoring and social networking facilities provided by Web 2.0 technologies, new pedagogic possibilities can be utilised in the classrooms".

The ideas presented in the previous paragraphs point out that nowadays, teaching is not only based on the use of written texts to read or write. Consequently, the 21 stcentury society, the changes proposed by the EHEA and the use of new technologies demand new forms of 'literacy'. Thanks to them students will be able to write texts with educational purposes through social networks such as Facebook or Twitter. Moreover, students will be able to use multimodal texts including videos and images in the classroom so that their learning process is easier, they can acquire competences that are important for the labour market and they can make the most of their learning process.

The main objectives of this article are the following: a) to show the relationship between the use of multimodal texts and resources in the classroom and the acquisition of social competences that will be useful for the labour market such as communication, cooperation, leadership or conflict management and b) to point out that promoting multimodality in the classroom implies that students develop multiliteracies and they are able to create their own way of working based on their own pace and way of learning, which contributes to promote autonomous learning.

Promoting that students learn being autonomous and using different multimodal resources implies that teachers help them to be aware of the different strategies they can use to improve their skills, always taking into consideration their individual characteristics (Benito, Bonson \& Icarán, 2005, p. 21). In this sense, we agree with Zabalza (2011: 86) in that methodology is the curricular component having more impact in their learning process. 
The creation of the EHEA highlights the importance of an effective teaching-learning process where teachers and students share the responsibility (Pereyra-García, Sevilla \& Luzón, 2006; Sánchez, 2006). Learning involves the acquisition of different competences that are necessary for the labour market, i.e., while learning at the University, students have to be able to apply theory to practice and to observe the relationship between what is learned at the University and their future live as professionals. Consequently, learning has to be progressive and it should make explicit the relationships between the different competences being developed with the different topics or activities. In this sense, formative evaluation should be promoted so that evaluation is understood as a whole, following Pérez-Paredes and Rubio (2005, p. 606-607): "Evaluation considers the teaching and learning program as a whole, and seeks to obtain feedback that can serve different purposes for the different agents in education, from teachers to curriculum designers".

Choosing formative evaluation implies that special importance is given to autonomous learning, i.e., university students are the protagonists of their teaching-learning process so that they can make the most of the acquisition of competences for their integral development so that they become active citizens in the present society (Hernández, 2003; Martínez Lirola, 2012; Teichler, 2006; Zabalza, 2002). As a consequence, when teaching languages, students have to work with real language and with authentic texts so that they can establish relationships between what they learn and life, following O'Keeffe, McCarthy and Carter (2007, p. 26):

Thus, when they (students) are presented with corpus examples, learners encounter real language as it is actually used, and in this sense it is 'authentic'. [...] Furthermore, one can argue that authentic texts are embedded in particular cultures and may be thus culturally opaque to those outside that (usually western) culture, and that it may, as a result, be next to impossible for learners to 'authenticate' such texts for themselves on this basis.

After this introduction, the next section is devoted to multimodality as a theoretical framework of this article because it frames the teaching practices explained in section four. The article has the following sections: section two explains the methodology used in this research. Then, section three describes the main characteristics of the participants and the context of this study. Section four concentrates on the description of some multimodal activities used in the teaching practices used in the subject English Language $V$ of the degree English Studies. Next, section five discusses the different competences and multiliteracies that students develop with the activities proposed. This section also offers the results of a survey with students' opinions about their experience of multimodal learning. Finally, the conclusions of the study are presented.

\section{Theoretical framework: Multimodality in the classroom}

The theory of multimodality developed through the work done by Kress and van Leeuwen $(2001,2006)$ and other authors (Baldry \& Thibault, 2006; Bezemer \& Jewett, 2010; Bowcher, 2012; Jewitt, 2009; Royce \& Bowcher, 2007, inter alia). Multimodality has contributed to understand how different modes of communication (language, images, graphs, sounds, music, gestures, etc.) create meanings. These modes are different semiotic resources that allow that meanings are created through one of them or through the combination of various ways simultaneously following Kress (2010, p.1):

Each mode does a specific thing: image shows what takes too long to read, and writing names what would be difficult to show. Colour is used to highlight specific aspects of the overall message. Without that division of semiotic labour, the sign, quite simply, would not work. Writing names and images shows, while colour frames and highlights; each to maximum effect and benefit. 
In this sense, Van Leeuwen $(2014$, p. 281) offers a very clear definition of multimodality: "The term multimodality refers to the integrated use of different semiotic resources (e.g. language, image, sound and music) in texts and communicative events". The image plays an important role in multimodal communication due to its capacity to capture attention (Kress \& Van Leeuwen, 2006; Kress, 2010; Unsworth, 2010).

There are extensive texts that use more than one mode to express their meanings. However, the use of multimodal texts is not really extended at tertiary education. These texts can be very useful to introduce cultural aspects into the classroom, to know other social realities and to make students improve their critical capacity. In addition, these types of texts can make students aware of how the said texts are designed and can be analysed, what aspects are explicit and what are implicit, how these texts can be used to integrate the different skills requested when learning foreign languages and what competences students can acquire with them.

To consider the classroom as a multimodal learning environment allows teachers and students to be aware of the potential that the modes of communication different from language have for teaching compared to traditional written texts used for reading and writing (Bearne et al., 2007; Knox, 2008; Walsh, 2009; Yelland, Lee, O'Rourke, \& Harrison, 2009), as Baldry and Thibault (2006, p. 21) make clear: "[...] multimodality refers to the diverse ways in which a number of distinct semiotic resource systems are both codeployed and co-contextualised in the making of a text-specific meaning".

Understanding the classroom as a multimodal environment makes that the different modes of communication used contribute so that the teaching-learning process is dynamic and creative, which facilitates students' learning process (Martínez Lirola, 2014). Moreover, if apart from being multimodal the texts deal with social topics such as intercultural aspects, ecology, gender issues, cultural differences, human rights, among others, there are many competences that can be promoted at tertiary education. In addition, students can be aware of their important role in society if they see themselves as active citizens by analysing the texts under analysis from a critical perspective.

The previous paragraphs have shown that multimodality concentrates on different modes of communication whereas the term 'multiliteracies' refers to the concrete practices of 'literacy', which implies that the said practices are necessary for communication in the present society. Simpson and Walsh (2010, p. 26) make clear that this is not a new term: "Evolving from the theorising on the New London Group (Cope \& Kalantzis, 2000), the term 'multiliteracies' was concerned with the many types of communication hended in new and different social and cultural contexts, and for both print and electronic texts".

\section{Methodology}

The subject English Language V of the degree English Studies (Grado en Estudios Ingleses) is a sixcredit subject, which implies that students spend 60 hours in the classroom and are also required to work 90 hours more, i.e., students needed to work individually and in groups inside and outside the classroom in order to acquire the competences established in the subject.

This subject was taught four hours per week, one theoretical and three practical. English Language $V$ is organised so that students can work with the different skills at the same time that they acquire social competences that help them to grow and to use in the labour market. In the theoretical lecture students were introduced to the main aspects of academic writing: cohesive devices, the structure of the academic essay and the main characteristics of different text types and their relationships with the context in which they are used. In the second hour, students were asked to prepare an oral presentation on a topic of their choice using multimodal resources.

Then, the next hour was used to revise grammar. Every lecture started with a brief theoretical explanation of the grammatical topic under study (i.e., the use of articles, reported speech, the passive voice, adverbs, etc.); thereafter some exercises were corrected so that students could put their grammatical knowledge into practice. The teacher always asked students how the grammatical point under analysis could be explained at the high school level so that students could act as teachers in the classroom. Finally, the last hour of the week consisted of a debate organised by the group who had presented the oral presentation in the previous class. The topic of the debate was the same as that of the oral presentation. 
Multimodality is promoted in the different modules of the subject so that students establish a connection between what happens in the classroom and real life at the same time that they are motivated to learn due to the variety of resources used in the teaching-learning process. The next section will pay attention to the main characteristics of the students that participate in this study.

\section{Participants and context}

The main objectives of this subject are that students develop the five skills (listening, speaking, reading, writing and interaction) for advanced students of English. This subject and English Language $\mathrm{VI}$ and VII, taught after this one, will allow students to achieve level C1 in English. Since most of the students wanted to be high school teachers, the lecturer made students think about the methodology and the different pedagogical techniques used in the classroom so that they could apply them in their future career as teachers.

Most of the students are 21 years old. The majority of them want to work as high school teachers but there are also students who would like to work in international companies as interpreters or translators. All these students have studied English in the previous two years of the degree (the level they achieve in the first year is B1 while B2 is the level they reach in the second year).

During the academic year 2015-2016, there were 93 students registered in the said subject. 73 were female and 20 were male. Out of the 93 students, there were 88 that came to class on a regular basis. The other five were Erasmus students who were studying at a different European University; therefore, they had the subject recognised.

\section{Introducing multimodality in the subject English Language V: Practical examples}

The following paragraphs offer concrete examples of the way in which the subject English Language $V$ incorporated multimodality to the different activities that were designed so that students could develop the five skills at the same time that they acquired social competences and developed multiliteracies.

- At the beginning of the semester, students learnt to analyse multimodal texts following the principles of visual grammar of Kress and van Leeuwen (2006) explained in the classroom. Consequently, students could read the visual and the written text and they could observe that the different linguistic and visual choices are not chosen at random but a determined communicative end. Different texts were analysed in the classroom so that students could put into practice what they have learned. Students could ask their doubts and the teacher provided feedback after the students have shared their analysis. Moreover, the structure of the academic essay was explained with a handout and with a video so that students were able to organise their ideas in the introduction, the body paragraphs and the conclusions in a logical way. At the end of the semester, students had to write an essay based on a multimodal text with social content. For example, some students chose a text about the way women are used in advertising; there were others who chose a text on gender violence, on the climatic change or on healthy lifestyles.

The fact that students had to analyse the written text and the image of a multimodal text as a unity made them aware of the way this type of texts are created and of the importance of the image in the global meaning of the texts. Students and teachers agreed that the essay students had to write in the final exam would be based on some of the topics students wrote about in the essay that had to hand in in the middle of the semester.

- The preparation of a cooperative oral presentation based on a social topic is a very clear example of multimodality. At the beginning of the semester, the teacher explained the characteristics of effective oral presentations using videos so that students could comment on the main positive aspects of each video and the ways in which they could be improved. Students needed to use different bibliographical references, including electronic ones, and to distinguish relevant from secondary information so that they become critical with the sources they use to prepare the presentation. Moreover, students needed to develop different interpersonal skills that contributed to the effective preparation and presentation of their work. This involved 
the balanced distribution of tasks, taking decisions about the organization of the presentation and listening actively to the different opinions, among others. In addition, students took the initiative of choosing a topic of their interest, of deciding the way the presentation was structured and of selecting the different multimodal resources they were going to use to present it in the classroom.

Most students made their oral presentations multimodal by using videos to illustrate some of the theoretical aspects used in the presentation. There were also some oral presentations in which students decided to use background music while they were doing the oral presentation in the classroom. For example, in a presentation about cultural aspects in the United States, the national anthem was used; in a presentation about China, students chose traditional Chinese music. There was also a presentation about tarot and it was accompanied by a mysterious music. One group decided to talk about life in Nepal and while the presentation was being done, a soft music of mantras could be heard.

Students were encouraged to decorate the classroom using multimodal resources such as posters or any visual element connected with the topic of the oral presentation. In this way, the whole classroom became multimodal and just by observing the decoration it was easy to deduce the different social topics that students had talked about.

- The debates that took place every week based on the same topic of the oral presentation also contributed to the use of multimodal resources. For example, some groups chose a video on the topic for discussion in order to introduce some ideas that could be used during the debate. Students shared the video in the Facebook of the subject so that students could have access to it before the debate. It is interesting that before the debate took place in the classroom, students had the chance to participate in the same debate writing their opinions in Facebook. The debate was started there with some questions prepared by the group in charge of this activity every week. After students had participated in the debate in Facebook, the group who has prepared it had to organise some conclusions of the main ideas shared and they needed to refer to them after the debate on the same topic was done in the classroom. Consequently, this is another way of integrating oral and written skills, cooperative work and the use of Information and Communication Technologies (hereafter ICTs) in the teaching-learning process.

This activity contrasts with the previous one because the intention of the presentation is that students use formal English whereas the debate has as its main purpose that students promote interaction with all students in the classroom. In this way, everybody had the opportunity of expressing her/his opinion about the topic presented in the debate. Moreover, the debate gave students the opportunity of learning from the opinions of others, working on classroom management, promoting creativity, organising the classroom in different ways, etc.

\section{Discussion: On the acquisition of competences and the development of multiliteracies through multimodality}

This section will explain the successes and challenges of using multimodal texts with social content so that students can acquire social competences while learning content. Moreover, the implications of using multimodal resources in a language classroom to develop multiliteracies will be studied.

The different activities presented in section four made students face some challenges when having to analyse the different elements in multimodal texts because traditionally, students were used just to analyse the written language. In this sense, students needed to learn to understand the multimodal text as a whole where the different modes of communication contributed to the meaning of the text. Moreover, writing an academic essay based on a multimodal text was another challenge because students were used just to write about a topic without using a text as a way of developing ideas. This activity was very successful because students were able to deconstruct the meaning of the multimodal texts chosen in order to develop their ideas for the introduction, body paragraphs and conclusion of the essay.

The preparation and participation in the group oral presentations and debates was quite challenging for students because they had to speak in front of an audience on a social topic of their choice. The power point presentation they prepared in order to present their topic was multimodal, which showed that they were able to combine different modes to communicate the meaning they wanted to share. The combination of the said 
modes was normally very successful because students were able to choose the right resources to share their message in an effective way.

Both the oral presentations and the debates are activities that contribute to the development of social competences because students have to be leaders whenever they have to take decisions about the topic they choose, the organization of it, the use of different references and resources so that the final result is coherent and gets the audience's attention. Moreover, these activities give students opportunities to solve conflicts whenever students disagree about any aspect during the preparation of the activities. Conflict solving is a skill that is very useful in life in general and in the labour market in particular. Needless to say that all the activities of the subject promote communication, which is an essential competence in a foreign language subject such as English Language V.

In addition, the fact that the different activities had to contribute to the introduction of cultural aspects and of social topics into the classroom was also challenging for students because this requested a relationship between the contents and topics shared in the classroom and real life. Working with cultural aspects and social issues gave students the opportunity of learning vocabulary connected with different semantic fields that would be really useful for their future life as professionals.

All the multimodal resources we have referred to contribute to the development of multiliteracies in the language classroom because students needed to be literate not only to read written language but they also had to deepen into the analysis and meaning of different modes of communication such as the analysis of visuals and music and their effects in their motivation. In fact, the use of multimodal resources and multiliteracies in the teaching-learning process contributed to motivate students to learn because they were free to choose different resources and to decide what topics they wanted to write and talk about in their essays, oral presentations and debates.

After what has been presented in the previous paragraphs, the oral presentations and the debates can be considered the two activities that incorporate more multimodal resources in the subject English Language $V$. The preparation of both activities requested the supervision of the teacher in group tutorials, where the teacher could pay attention to different aspects such as: the structure and the content of the presentation, the use of ICTs and multimodal resources, the cooperation between the different group members so that the presentation was effective and the acquisition of some social competences such as communication or conflict solving during the preparation of the said activities.

Multimodal oral presentations and debates request the integration of different modes of communication, the combination of different pedagogical techniques and technical resources so that everything is combined in the right way so that learning is significant. Moreover, teachers and students need to share the responsibility during the teaching-learning process and students become the protagonists while they are learning, which has a direct effect in motivation.

A survey was prepared in order to observe if students were aware of the different multimodal resources used in the classroom and the different competences being acquired (see appendix 1). Following Herrera and Enrique (2008, p. 13), we consider that the survey is appropriate to do research because it offers objective information on what students think about a particular topic.

The survey was distributed at the end of the semester, i.e., once students were familiar with the multimodal methodology already mentioned. The participants completed the survey by hand. Most of the questions are closed (see appendix 1) although there is also an open question so that students can express their opinions. The answers that students provided were anonymous. The teacher interpreted the results of the survey by considering the answers that students had provided, as we can see in the following paragraphs.

Question one asked students if they were aware of being immersed in a multimodal teaching-learning process and all the students offered a positive answer. The second question paid attention to what of the different proposed modes of communication, i.e., the explanations provided by the teacher in the theoreticalpractical lectures, preparation of cooperative oral presentations, the texts written in Facebook, doing oral and written exercises in the classroom and at home and participation of the debates in the classroom, are more helpful for students. It is outstanding that $74,57 \%$ students point out that the combination of all of them 
as is being done in the subject English Language V. Students who have not marked all the options give importance to the oral presentations and the debates.

The third question tried to observe if students consider that a multimodal teaching-learning process and continuous evaluation paying attention to the different skills have an effect in their motivation to learn. Almost all students, $98,30 \%$, with the exception of one person (1.7\%), stated that the fact that the subject is multimodal has a direct effect in their motivation. ${ }^{32}$

The fourth question concentrated on the main competences students consider that they have acquired more in the subject out of the following ones: critical thinking, communication, leadership, writing properly in English, the use of ICTs, group work and autonomous learning Most students chose different competences being group work and communication the ones chosen by most people $(72,88 \%)$; autonomous learning was also selected by $57,32 \%$ followed by writing properly in English chosen by $53,82 \%$.

We designed question number five because we were interested in knowing if students had some suggestions about how to use other multimodal resources in English Language $V$ to facilitate the way students learn. The majority of students, $85 \%$ considered that the subject was well designed and taught as it was and, consequently, they did not make any suggestions. Nevertheless, $15 \%$ of students proposed the organization of conversations or debates with native speakers. In addition, some students suggested incorporating the preparation of a video or the creation of a blog in groups to the evaluation of the subject. They make clear that these activities would integrate the use of different skills and the use of ICTs, as it happens also when students have to participate in the debate in Facebook or in the oral presentations (see the beginning of this section).

Question number six concentrated on the role of tutorials in the multimodal teaching-learning process. $55 \%$ of students considered them essential to supervise the way students work and learn; $35 \%$ considered them necessary up to a certain extend and only $10 \%$ commented that they could do without them. ${ }^{4}$

Since this is not a specific article about tutorials, we are not going to deepen into their role in high education. However, we consider that tutorials are essential in an experience of multimodal learning as the one presented in this article due to the fact that teachers need to have different roles in the teaching-learning process such as the following: guide, tutor, coach, among others. In other words, teachers need to guide and support students so that they develop the different activities mentioned. Following Cano González (2009) and Garcia et al. (2005), we understand tutorials as one of our responsibilities as teachers because tutorials contribute to establish a personalized relationship between teachers and students.

\section{Conclusions}

Designing the teaching-learning process in the subject English Language $V$ as multimodal contributes to the development of multiliteracies and competences in students so that what they learn in the classroom is connected with real life. The subject promotes students' responsibility in the teaching-learning process because they have to assume an active role while they learn due to the fact that they have to take decisions and be responsible of the different tasks they prepare following the guidelines presented by the teacher at the beginning of the semester.

The use of different multimodal strategies (videos, Facebook, multimodal texts with images, among others) favours students' creativity because they make an effort to use different techniques or resources to improve interaction with their classmates in the classroom. Moreover, creativity is promoted because students can be asked to search for texts of their interest and then these texts can be used to analyse cultural aspects or social problems. In addition, the fact that the subject supports the use of different multimodal resources for the learning process and for the evaluation establishes a direct relationship between the subject and real life

\footnotetext{
${ }^{3}$ For specific studies on the motivation of university students, see the following references: Crespo and Martínez Lirola, 2008; Martínez Lirola and Crespo, 2008.

${ }^{4}$ For specific studies on University tutorials see the following articles Martínez Lirola (2007) (2008); Martínez Lirola and Crespo (2009a) and (2009b).
} 
because society is multimodal in different ways as we can observe in television, advertising, social networks, among others.

Multimodal classes facilitate the learning process and make students be creative, active and autonomous while they learn. This implies that students acquire competences apart from learning contents, which will be essential for their live in general and for the labour market in particular. Emphasizing that students are the protagonists and the leaders in the teaching-learning process makes them be prepared to take decisions constantly about different things such as: the text they choose to write their essay, the topic of the oral presentation and its organization using multimodal resources, the comments they write through Facebook on the topic suggested for debate every week and the way they contribute to group interaction.

\section{References}

Baldry, A. \& Thibault, P. (2006). Multimodal transcription and text analysis. London: Equinox.

Bearne, E., Clark, C., Johnson, A., Manford P., Mottram, M. \& Wolstencroft, H. (2007). Reading on screen research report. London: United Kingdom Literacy Association.

Benito, A., Bonson, M. \& Icarán, E. (2005). Metodologías activas. In A. Benito and A. Cruz (Coords.), Nuevas claves para la docencia universitaria en el Espacio Europeo de Educación Superior. Madrid: Narcea. pp. 21-64

Benito, A. \& Cruz, A. (2005). Introducción. In A. Benito and A. Cruz (Coords.), Nuevas claves para la docencia universitaria en el Espacio Europeo de Educación Superior. Madrid: Narcea. pp. 11-21

Bezemer, J. \& Jewett, C. (2010). Multimodal analysis: Key Issues. In L. Litosseliti, (Ed.), Research methods in linguistics. London: Continuum. pp. 181-197

Bowcher, W.L. (Ed.) (2012) Multimodal texts from around the world: Cultural and linguistic insights. London: Palgrave.

Bueno González, A. \& Nieto García, J.M. (2009). English language teaching in the European Higher Education Area (EHEA): Towards uniformity or diversity? In M.L. Pérez Cañado (Ed.), English language teaching in the European Credit Transfer System. Facing the Challenge. Bern: Peter Lang. pp. 55-72

Cano González, R. (2009). Tutoría universitaria y aprendizaje por competencias. ¿Cómo lograrlo? REIFOP,12 (1),181-204. http://www.aufop.com/). (Retrieved on: 13-1-2016).

Christie, F. \& Simpson, A. (2010). Literacy and social responsibility. London: Equinox.

Coffin, C. (2012). Editorial. English for Academic Purposes: Contributions from systemic functional linguistics and academic literacies. Journal of English for Academic Purposes, 11, 1-3.

Cope, B. \& Kalantzis, M. (eds.) (2000). Multiliteracies: Literacy learning and the design of social futures. South Yarra: Macmillan.

Crespo, E. \& Martínez Lirola, M. (2008). Convergencia europea, motivación y actuación docente en el aula universitaria [European convergence, motivation and teaching performance in the university classroom]. Revista de Enseñanza Universitaria, 31, 4-16. http://institucional.us.es/revistas/revistas/universitaria/htm/indice.htm (Retrieved on: 13-1-2016).

García Nieto, N. (dtor.), Asensio Muñoz, I., Carballo Santaolalla, R., García García, M. \& Guardia González, S. (2005). La tutoría universitaria ante el proceso de harmonización europea. Revista de Educación, 337, 189-210.

Healy, A. (2008). Multiliteracies and Diversity in Education. South Melbourne: Oxford.

Hernández, F. (2003). Enseñar y aprender en la Universidad: una adaptación necesaria de las titulaciones al Espacio Europeo de Educación Superior. Circunstancia, Revista de Ciencias Sociales, 8, 173-190.

Herrera, L. and Enrique, C. (2008). Proyectos de innovación en tutorías en la Universidad de Granada: análisis de los instrumentos empleados. Profesorado. Revista de Currículum y Formación del Profesorado, 12(2). http://www.ugr.es/local/recfpro/rev122COL5.pdf (Retrieved on: 14-1- 2016). 
Hestbaek A. T., Maegerф, E. \& Tonnessen, E.S. (2015). Social semiotics: Key figures, new directions. London: Roudledge.

Jewitt, C. (ed.) (2009). The Routledge handbook of multimodal analysis. London: Routledge.

Knox, J.S. (2008). Online newspaper and TESOL classrooms: a multimodal perspective. In L. Unsworth (Ed.), Multimodal semiotics. Functional analysis in contexts of education. London: Continuum. pp. 139-158

Kress, G. \& van Leeuwen, T. (2001). Multimodal discourse. London: Routledge.

Kress, G. \& van Leeuwen, T. (2006). Reading images: The grammar of visual design. Second edition. London: Routledge.

Kress, G. (2010). Multimodality. A social semiotic approach to contemporary communication. London: Routledge.

Lemke, J.L. (2012). Multimedia and discourse analysis. In J. P. Gee and M. Handford (Eds.), The Routledge handbook of discourse analysis. London: Routledge. pp. 79-89

Livingstone, S. (2008). Digital literacies: Tracing the implications for learners and learning. Bristol: Economic and Social Research Council.

López Noguero, F. (2005). Metodología participativa en la enseñanza universitaria. Madrid: Narcea.

Martínez Lirola, M. (2007). El nuevo papel del profesor universitario en el proceso de convergencia europea y su relación con la interacción, la tutoría y el aprendizaje autónomo. Porta Linguarum. Revista Internacional de Didáctica de las Lenguas Extranjeras, 7, 31-43.

Martínez Lirola, M. (2008). Explorando las tutorías en el proceso de convergencia europea Revista de $\begin{array}{lll}\text { Enseñanza } \quad \text { Universitaria, } & \text { 29-36. }\end{array}$ http://institucional.us.es/revistas/revistas/universitaria/pdf/REU/32/03.pdf (Retrieved on: 20-1-2016).

Martínez Lirola, M. (2012). Evaluation proposal based on the ECTS system: evaluating the four skills in a University core subject with a portfolio. Porta Linguarum, 17, 189-201.

Martínez Lirola, M. (2014) Propuesta de enseñanza multimodal en una asignatura de lengua inglesa. Encuentro. Revista de investigación e innovación en la clase de idiomas, 23, 89-101.

Martínez Lirola, M. \& Crespo, E. (2008). Explorando las variables incidentes en la motivación del alumno de Filología Inglesa en el ámbito del Espacio Europeo de Educación Superior. In G. Merma Molina and F. Pastor Verdú (Coords.), Aportaciones curriculares para la interacción en el aprendizaje. Redes de Investigación Docente- Espacio Europeo de Educación Superior. 1, pp. 119-135.

Martínez Lirola, M. \& Crespo, E. (2009a) La tutoría universitaria en el modelo de la convergencia europea. In C. Gómez Lucas \& S. Grau Company (Eds.), Propuestas de diseño e innovaciones curriculares y metodología en el EEES. Alcoy: Marfil. pp. 451-466

Martínez Lirola, M. \& Crespo, E. (2009b) La importancia de las tutorías en el marco del EEES. VII Jornadas de Redes de Investigación en Docencia Universitaria. La calidad del proceso de enseñanzaaprendizaje universitario desde la perspectiva del cambio. Alcoy: Marfil. pp. 499-504.

Merchant, G. (2009). Literacy in virtual worlds. Journal of Research in Reading, 32(1), 38-56.

O'Keeffe, A., McCarthy, M. \& Carter, R. (2007). From corpus to classroom: Language use and language teaching. Cambridge: Cambridge Language Teaching Library.

PereyraGarcía, M. A., Sevilla, M. \& Luzón, A. (2006). Las universidades españolas y el proceso de la construcción del Espacio Europeo de Eduación Superior. Limitaciones y perspectivas de cambio. Revista española de educación comparada 12, 37-80.

Pérez Paredes, P. \& Rubio, F. (2005). Testing and assessment. In D. Madrid, N. Mclaren \& A. Bueno (Eds.), TEFL in secondary education. Granada: Universidad de Granada. pp. 605-639

Royce, T.D. \& Bowcher, W. L. (Eds.) (2007). New directions in the analysis of multimodal discourse. Londres: Lawrence Erlbaum Associates. 
Sánchez, A. (2006). Innovación en la construcción del Espacio Europeo de Educación Superior: camino de Londres 2007. Foro de Educación, 7-8, 119-129.

Simpson, A. \& Walsh, M. (2010). Múltiple literacies: implications for changed pedagogy. In F. Christie \& A. Simpson (Eds.), Literacy and social responsibility. London: Equinox. pp. 24-39

Teichler, U. (2006). El Espacio Europeo de Educación Superior: visiones y realidades de un proceso deseable de convergencia. Revista Española de Educación Comparada, 12, 113-144.

Unsworth, $L$ (2001). Teaching multiliteracies across the curriculum: Changing contexts of text and image in classroom practice. Philadelphia: Open University Press.

Unsworth, L. (ed.) (2008a). New literacies and the English curriculum. London: Continuum.

Unsworth, L. (ed.) (2008b). Multimodal semiotics. Functional analysis in contexts of education. London: Continuum.

Unsworth, L. (2010). Resourcing multimodal literacy pedagogy. Toward a description of the meaning-making resources of language-image interaction. In T. Locke (ed.), Beyond the grammar wars. London: Routledge. pp. 276-293

Walsh, M. (2009). Pedagogic potentials of multiple literacies. In L. Tan Wee Hin \& R. Subramanian (Eds.), Handbook of research on new media literacy at the K-12 level: Issues and challenges. Hershey, PA: IGI Global. pp. 32-47

Van Leeuwen, T. (2014) Critical discourse analysis and multimodality. In C. Hart, \& P. Cap (eds.), Contemporary critical discourse studies (). Bloomsbury: Bloomsbury Publishing. pp. 281-295

Yelland, N., Lee, L., O'Rourke, M. \& Harrison, C. (2009). Rethinking pathways to print literacy: a multiliteracies perspective. Practically Primary 14(1), 4-6.

Zabalza, M. A. (2002). Diseño curricular en la Universidad. Competencias del docente universitario. Madrid: Narcea.

Zabalza, M. A. (2011) Metodología docente. Revista de Docencia Universitaria REDU. Monográfico El espacio europeo de educación superior. ¿Hacia dónde va la Universidad Europea?, 9(3), 75-98. http://redaberta.usc.es/redu (Retrieved on: 18-2-2016)

Received: 02/03/2016

Accepted: 15/05/2016 


\section{Appendix 1: Survey on multimodal teaching}

1. Have you been aware of the multimodal teaching-learning process during the semester in the subject English Language $V$ ?

Yes

No

2. Which of the following ways of communication has been more helpful during your learning process? (You can give a percentage to each one)

- $\quad$ Explanations of the teacher in the theoretical-practical sections.

- $\quad$ Preparation and presentation of the group oral presentations.

- $\quad$ Writing texts through Facebook.

- $\quad$ Preparation of oral and written exercises in the classroom and at home.

- $\quad$ Participation in the debates in the classroom.-

- $\quad$ Others (please, specify)

3. Are you more motivated to learn due to the fact that the subject is multimodal and it is evaluated during the whole semester paying attention to the different skills?

Yes

No

4. Which of the following competences do you consider you have developed more in this subject? (you can give a percentage to each one)

- Critical thinking

- Writing in English in an appropriate way

- Use of ICTs - Doing group work

- Autonomous learning

- Communication

- Conflict solving

- Leadership

- Others (specify)

5. How could the subject English Language $V$ become more multimodal in order to facilitate your learning process even more?

6. What role is played by tutorials in your multimodal learning process?

- $\quad$ They are essential.

- $\quad$ They are important up to a certain extent.

- $\quad$ They are not necessary. 